\title{
Obraz wartości PRL w komiksie Henryka Jerzego Chmielewskiego Tytus, Romek i A'Tomek (analiza ksiąg z lat 1966-1987)
}

Seria komiksowa Henryka Jerzego Chmielewskiego powstaje nieprzerwanie od roku $1957 \mathrm{i}$ bez wątpienia jest jedną z najbardziej popularnych serii tego typu w Polsce. Pierwotnie autor publikował komiksowe opowieści o Tytusie, Romku i A’Tomku na łamach harcerskiego periodyku „Świat Młodych” (notabene rozpowszechnianego w nakładzie 500 tys. egzemplarzy, co świadczyć może o dużej rozpoznawalności komiksu). Po dziewięciu latach zdecydowano o ukazywaniu się historyjek rysunkowych w formie zamkniętych zeszytów, zwanych księgami.

Do chwili obecnej ukazało się łącznie 31 ksiąg (księgi z okresu PRL oraz wczesnych lat 90. doczekały się wznowienia w 2009 roku nakładem wydawnictwa Prószyński Media) oraz sześć tomików specjalnych, osadzonych w realiach przełomowych wydarzeń historycznych, jak Bitwa Warszawska czy Powstanie Warszawskie. Przygody Tytusa zamieszczane na łamach „Świata Młodych" współcześni czytelnicy mogą znaleźć w Księdze Zero ${ }^{1}$ oraz Księdze 80-lecia ${ }^{2}$. Publikowano także rozproszone epizody okolicznościowe na łamach współczesnej polskiej prasy po roku $1990^{3}$.

\section{Założenia badawcze}

Celem artykułu jest analiza ksiąg wydawanych w latach 1966-1987 i uzyskanie odpowiedzi na następujące pytania:

* Dr, e-mail: krzysztof.grzegorzewski@uni.lodz.pl; Uniwersytet Łódzki, Wydział Filologiczny, Katedra Dziennikarstwa i Komunikacji Społecznej.

${ }^{1}$ H.J. Chmielewski, Tytus, Romek i A'Tomek. Księga Zero, Egmont Polska, Warszawa 2002.

${ }^{2}$ H.J. Chmielewski, Tytus, Romek i A'Tomek. Ksiega 80-lecia, Egmont Polska, Warszawa 2003.

${ }^{3}$ Zob. www.tytusromekiatomek.pl [dostęp: 22.01.2017]. 
1) Jaki obraz rzeczywistości oraz wartości propagowanych w PRL wyłania się z kart komiksu i jak wyglądała jego ewolucja?

2) Jak rozwijali się główni bohaterowie komiksu, począwszy od pierwszej księgi, gdzie przedstawiono ich jako modelową młodzież PRL?

3) Jakim językiem i stylem posługiwał się autor w swoich komiksach i jakim zmianom podlegał ten język do ostatniego tomu wydanego przed transformacją ustrojową?

Nie ulega wątpliwości, że charakter otwierającej serię Księgi I był w równej mierze rozrywkowy, jak propagandowy - w wydanej bowiem w 2008 roku autobiografii autor wyjaśnia:

Wydawnictwo Harcerskie mogło wydawać książki tylko o tematyce harcerskiej, a więc i Księga Tytusowa musiała być nasycona tematami harcersko-wychowawczymi. O żadnej serii książeczek Tytusa, Romka i A’Tomka nikt jeszcze nie śmiał marzyć.

Dostałem z Wydawnictwa listę treści, które powinna zawierać książeczka:

1. Romek i A’Tomek mają być w mundurkach harcerskich i mieć czerwone chusty.

2. Romek i A'Tomek robią test, czy Tytus nadaje się do ZHP.

3.Życie obozowe i harcerski bieg terenowy.

4. Igrzyska sportowe, urządzenie kąpieliska.

5. Harcerz miłuje przyrodę, hodowla zwierzątka.

6.Pomoc słabszym na szlaku „Niewidzialnej Ręki”.

7. Własny grosz, zarabianie pieniędzy na obóz.

8. Ochrona zabytków i walka z przesądami.

I to wszystko miałem zamieścić na 56 stronach książeczki, okraszonych humorem w myśl zasady: „ucząc bawi, bawiąc uczy”4.

Ostatecznie pierwszy komiks z serii ukazał się w 1966 roku (a więc na 1000-lecie Państwa Polskiego). Dowodem na jego poczytność był fakt, że 30 tys. wydrukowanych egzemplarzy sprzedano w ciągu tygodnia ${ }^{5}$. Księga I istotnie zawierała wszystkie narzucone Chmielewskiemu treści propagandowe. Były one dostrzegalne także w kolejnych księgach, wydawanych w latach 60. i 70., choć ich nasilenie było różne, na ogół konsekwentnie mniejsze. Bez wątpienia propaganda PRL - choć starannie ukryta pod powierzchnią mniej lub bardziej zabawnych przygód Tytusa, Romka i A’Tomka - była obecna przynajmniej do końca lat 70 . Wydaje się, że do sklasyfikowania oraz oceny jej charakteru najbardziej przydatne będą stanowiska badaczy propagandy zebrane przez Bogusławę Dobek-Ostro-

${ }^{4}$ Por. H.J. Chmielewski, Tytus zlustrowany. Autobiografia na tle historii komiksu pt. „Tytus, Romek i A'Tomek”, Opole 2006. Cyt. za: Tenże, Tytus, Romek i A’Tomek. Księga I, Prószyński Media, Warszawa 2009, s. 56.

${ }^{5}$ Tamże. 
wską, Beatę Ociepkę i Janinę Fras, a szczególnie jedno, zwane komunikowaniem perswazyjnym, opisane jako

proces akceptacji i adaptacji nowych zachowań (reakcji) w sposób dobrowolny przez odbiorcę, który pozostaje w związku z nadawcą. Związek ten może mieć charakter symboli werbalnych lub niewerbalnych. Perswadujący stara się wpłynąć na zmianę zachowań (reakcji) lub wzmocnienie istniejących postaw ${ }^{6}$.

Bez wątpienia o to chodziło właśnie wydawnictwu, które przesłało Chmielewskiemu cytowaną wyżej listę treści - by propagować ideę zrzeszania się w organizacjach społecznych, cechujących się do tego specyficznym wewnętrznym reżimem i ściśle określonymi zasadami (tu: ZHP); podejmowania prac społecznych; aktywnej postawy wobec rzeczywistości, chęci jej ulepszenia i naprawy (przez pomaganie słabszym, liczne pomysły racjonalizatorskie itd.); wzorowej postawy uczniowskiej i pilnego wypełniania obowiązków szkolnych; koncentrowania się na wartościach zbiorowych kosztem wartości indywidualnych itd. Charakterystyczna wydaje się walka z przesądami, która w odniesieniu do PRL powinna być traktowana jako niezbędny element w kształtowaniu ateistycznego społeczeństwa.

Sama propaganda jest starannie ukryta. Chmielewski starał się unikać używania jakichkolwiek określeń związanych z rzeczywistością ustrojową czy w ogóle kojarzących się z polityką (socjalizm, czyn społeczny, bratnia przyjaźń - ich ślady można znaleźć dopiero pod koniec tego okresu, ale w zupełnie innej funkcji). Zidentyfikowanie treści propagandowych jest obecnie możliwe dzięki zyskaniu elementarnej, zgodnej ze stanem faktycznym (a więc niezakłamanej) wiedzy z zakresu historii politycznej Polski z tamtego okresu' ${ }^{7}$ a także - w niezbędnym zakresie - historii politycznej świata ${ }^{8}$. W owym czasie podczas lektury czytelnik musiałby interesować się rzeczywistością polityczną i społeczną państwa, najważniejszymi wydarzeniami zagranicznymi, a także realiami krajów zarówno Zachodu, jak i tzw. obozu socjalistycznego - mając przy tym dostęp do wiarygodnych źródeł informacji. W latach 60 . i 70. - charakteryzujących się nieco większą otwartością na kulturę okcydentalną niż w okresie stalinizmu - dostęp taki oznaczałby czytanie zagranicznych publikacji, słuchanie Radia Wolna Europa bądź Głosu Ameryki, korzystanie z „podziemnych” wydawnictw nieobjętych kontrolą cenzury. Należy jednak zaznaczyć, że w początkowym okresie wydawania serii nie istniała jeszcze opozycja polityczna, która taki „drugi obieg”

${ }^{6}$ B. Dobek-Ostrowska, J. Fras, B. Ociepka, Teoria i praktyka propagandy, Wydawnictwo Uniwersytetu Wrocławskiego, Wrocław 1999, s. 9-10.

${ }^{7}$ A.L. Sowa, Historia polityczna Polski 1944-1941, Wydawnictwo Literackie, Kraków 2011.

${ }^{8}$ Historia polityczna świata XX wieku. 1945-2000, red. M. Bankowicz, Wydawnictwo Uniwersytetu Jagiellońskiego, Kraków 2004. 
byłaby w stanie wytworzyć (zaczął on powstawać dopiero w drugiej połowie lat 70., osiągając apogeum swojej działalności dekadę później ${ }^{9}$ ). Osobną sprawą pozostają możliwości interpretacji takich treści, a z faktu, że odbiorcami komiksów była młodzież szkolna, można wyciągnąć wniosek, że zarówno wiedza polityczno-historyczna, jak i możliwości ówczesnych czytelników komiksu były niskie bądź żadne. Propaganda na jego łamach mogła więc być i - zapewne - była skuteczna.

Niezwykle inspirująca w pracy nad analizą komiksu okazała się książka Hanny Świdy-Ziemby Młodzież PRL. Portrety pokoleń w kontekście historii ${ }^{10}$. Zaproponowany przez autorkę (wynikający z wieloletniej, prowadzonej w ukryciu pracy socjologicznej) podział młodzieży PRL-owskiej na następujące po sobie pokolenia, pozwolił przyjrzeć się bohaterom komiksu, sklasyfikować ich postawy, a tym samym pełniej odpowiedzieć na pytanie o cele perswazyjne komiksu oraz ewolucję tych celów. Świda-Ziemba charakteryzuje pokolenia nie tylko w ścisłym związku z historią polityczną poszczególnych dekad PRL, lecz także z trafnie zdefiniowanymi totalitarnymi scenariuszami społeczno-politycznymi, wdrażanymi przez ekipy poszczególnych komunistycznych przywódców. Ślady istnienia takich scenariuszy oraz samych pokoleń młodzieży PRL można znaleźć także w serii komiksowej Chmielewskiego.

\section{Ogólna charakterystyka komiksu}

Głównymi bohaterami serii komiksu są: uczłowieczany szympans Tytus de Zoo oraz dwaj sprawujący nad nim opiekę harcerze w wieku szkolnym - Romek i A’Tomek. Na kartach poszczególnych ksiąg chłopcy uczestniczą w szeregu przygód, niekiedy całkowicie nieprawdopodobnych, innym razem mocniej osadzonych w realiach ówczesnej Polski. Jako harcerze jeżdżą na obozy, biorą udział we wspólnych organizowanych przez ZHP przedsięwzięciach, a nawet uczestniczą w ćwiczeniach wojskowych; podróżują po tajemniczych, istniejących bądź nieistniejących krainach, niekiedy zabawnych i śmiesznych do granic absurdu; przenoszą się w czasie i bywają świadkami zamierzchłych epok historycznych lub epokowych wydarzeń. Wykreowana przez Chmielewskiego rzeczywistość jest niezwykle bogata i pomysłowa - trzeba zauważyć, że stosunkowo rzadko akcja ksiąg rozgrywa się w kraju i w konkretnych jego częściach, choć i tak się zdarza. Fantastyczna rzeczywistość - zwłaszcza w dalszych księgach - sprawia, że przekaz wspomnianych wyżej wartości propagowanych w PRL pozostaje zawoalowany. Opowieści

\footnotetext{
${ }^{9}$ Por. audycje red. (obecnie prof. nadzw. UŁ) Konrada Tatarowskiego Przegląd prasy podziemnej, nadawane w latach 80. w Radiu Wolna Europa.

${ }^{10}$ H. Świda-Ziemba, Młodzież PRL. Portrety pokoleń w kontekście historii, Wydawnictwo Literackie, Kraków 2010.
} 
są pełne humoru, dystansu, ale niemal zawsze zawierają treści dydaktyczno-wychowawcze (najbardziej widoczne w początkowych numerach serii).

Nad bohaterami czuwa Papcio Chmiel (obecny w komiksie w licznych autotelicznych wtrętach) oraz - w wybranych epizodach - zwariowany naukowiec-wynalazca, prof. T. Alent. Zwraca natomiast uwagę fakt, że w żadnym zeszycie nie są przedstawieni - bodaj epizodycznie - ewentualni rodzice bądź dalsza rodzina chłopców. W niektórych księgach Chmielewski wspomina o przodkach Tytusa zamieszkałych w Trapezfiku w Afryce Środkowej, nie ma jednak wzmianki o tym, by Romek czy A’Tomek mieli normalne rodziny. W licznych zeszytach serii chłopcy mieszkają razem. Być może ma to związek z cechą charakterystyczną dla ustrojów totalitarnych opartych na modelu sowieckim, w których rola rodziny była ograniczana do minimum, a nierzadko negowana ${ }^{11}$; rodzinę $\mathrm{w}$ wychowaniu młodych pokoleń socjalistycznej młodzieży miały zastąpić państwowe organizacje młodzieżowe.

Na początku serii komiksowej Romek i A’Tomek noszą wszelkie cechy modelowej młodzieży PRL: nie wyróżniają się zbytnio indywidualnością, posłusznie wypełniają wszystkie obowiązki szkolne, z pasją angażują się w harcerstwo. Obaj chłopcy są w pierwszych księgach ubrani w mundurki harcerskie oraz czerwone chusty. Chmielewski, tworząc te postacie, wykorzystuje popularny w przekazach komicznych kontrast „mały - gruby” i „duży - chudy” (odpowiednio A’Tomek i Romek). Jedynie Tytus chodzi w sportowych butach, szortach oraz czerwonej koszulce z napisem TYTUS - jest to najczęściej spotykany u tego bohatera strój i zarazem jego cecha indentyfikacyjna (notabene wykorzystywana do dziś w przekazach marketingowych związanych z komiksem). Język, jakim komunikują się bohaterowie, jest początkowo infantylny, pełen opartych na prostych rymach wierszyków oraz szkolnych piosenek. Z czasem zaczyna się wypełniać elementami humoru, niekiedy ironii, szyderstwa, złośliwości, a nawet werbalnej agresji. Świadczy to zresztą o stopniowym indywidualizowaniu się charakterów postaci, które zostanie wykazane w analizie poszczególnych tomików.

\section{Analiza ksiąg}

W Księdze I (1966) poznajemy Romka i A’Tomka jako wzorowych harcerzy, którzy mają zadanie sprawdzić, czy Tytus de Zoo nadaje się do harcerstwa oraz zwerbować go do tej organizacji. Obaj chłopcy noszą wspomniane harcerskie mundurki, a przed pierwszym spotkaniem wymieniają uwagi:

\footnotetext{
${ }^{11}$ Por. H. Świda-Ziemba, dz. cyt., s. 98-130 (opis pokolenia „ZMP-owskich wyznawców ideologii"), a także obraz rzeczywistości Korei Północnej i sposób kształcenia młodego pokolenia Koreańczyków w filmie dokumentalnym Defilada, reż. A. Fidyk, prod. Poltel, Warszawa 1989.
} 
Romek (o Tytusie): Spóźnia się na próbę.

A'Tomek: Może się załamat?

Tytus: Nie załamałem się, tylko troche mnie przygięto.

(Ksiegga I, s. 4)

Spóźnienie się na pierwszą próbę jest identyfikowane z załamaniem się. Słowa A’Tomka przywodzą na myśl wszystkie cechy ZMP-owskiego aktywisty z pierwszej połowy lat 50. w PRL: całkowicie oddanego sprawie, obowiązkowego, zaangażowanego ideowo. Narzucone wartości harcerskie Chmielewski realizuje czasem nieco groteskowo: A’Tomek, przekonany o konieczności hodowania jakiegoś zwierzęcia, wyprowadza na spacer do stawu swojego karpia. Promując inne wartości, autor posługuje się hiperbolą posuniętą niekiedy do granic groteski: na s. 23-24 prezentuje bowiem skutki spożywania alkoholu, który gwałtownie postarza, przemieniając młodych bohaterów w staruszków. Ten sposób przedstawienia przywodzi na myśl nachalną propagandę antyalkoholową widoczną w Polskiej Kronice Filmowej w latach 50. i $60 .{ }^{12}$, ale równocześnie zabawnie $\mathrm{z}$ nią kontrastuje.

W pierwszej księdze nie brakuje także kultu i współzawodnictwa pracy, licznych pomysłów racjonalizatorskich, chęci ulepszania i poprawiania dookólnej rzeczywistości. Na s. 14 Romek stwierdza: „Piękny zamek. Można by tu urządzić harcówkę albo punkt turystyczny" - cytat ten pokazuje charakterystyczne dla epoki PRL wykorzystanie znacjonalizowanego mienia zabytkowego, gdzie na ogół tworzono placówki publiczne ${ }^{13}$. Do wspomnianych wcześniej pomysłów racjonalizatorskich można zaliczyć również zorganizowanie przez Tytusa straży obozu harcerskiego przy pomocy kukły i magnetofonu z sygnałem alarmowym (s. 41), a także stworzenie spółdzielni zwanej Wielodromem (s. 28-29) i samodzielne zarabianie pieniędzy przeznaczonych na zbudowanie obozu harcerskiego.

Księga I kończy się happy endem: wstąpieniem Tytusa do ZHP - wyidealizowanej organizacji młodzieżowej, która stanowi jedyny punkt zaczepienia sugerujący, że miejscem akcji jest PRL. Przedstawiona rzeczywistość jest przejrzysta, pozbawiona dysonansów, nie wymaga od bohaterów jakichkolwiek niejednoznacznych zachowań czy trudnych wyborów. Przygody chłopców opierają się na wartościach i poglądach scharakteryzowanego przez Świdę-Ziembę „pokolenia małej reformy” 14 z czasów „małej stabilizacji” Władysława Gomułki. Bohaterowie komiksu akceptują zastaną rzeczywistość, aktywnie angażują się w życie

\footnotetext{
12 Por. Propaganda PRL-u. Najzabawniejsze kroniki filmowe, wyd. Grube Ryby, Warszawa 2006 (kroniki filmowe pt. Pije Kuba..., Wóda!, Wstap na piwko na przeciwko, Ale suszy...).

${ }^{13}$ Por. przypadek zabytkowego Pałacu Heinzla w łódzkich Łagiewnikach - w latach 80. XX w. mieścił się tam Szpital Chorób Płuc, oddział B (dla małych dzieci). Obecnie obiekt niszczeje, sprywatyzowany w latach 90 .
}

${ }^{14}$ H. Świda-Ziemba, dz. cyt., s. 359-364. 
społeczne, chętnie przynależą harcerskiej organizacji i próbują dokonywać owej „małej reformy”: naprawiać rzeczywistość wokół siebie przez rozmaite inicjatywy. Kończą się one różnym skutkiem, często pozytywnym, niekiedy po prostu zabawnym - niemniej ich podejmowanie jest możliwe i mile widziane (w przeciwieństwie do realiów tego okresu w PRL).

W Księdze II (1967) mamy do czynienia z utrwalaniem tego obrazu: zwariowany, ale pojętny i sympatyczny szympans, dzielny i zaangażowany zastępowy-organizator oraz harcerz niewyróżniający się niczym szczególnym poznają tajniki ruchu drogowego. Dydaktyzm tego zeszytu wydaje się wręcz natrętny: „uspołeczniony” kierowca bezinteresownie zatrzymuje samochód, by zwrócić chłopcom uwagę, że łamią konkretny przepis (s. 11), mechaniczny koń Rozalia prowadzi ich na kurs do Młodzieżowej Służby Ruchu organizowanej przez ZHP (s. 16-17). Pojawiają się również liczne elementy wychowawcze, jak walka z chuliganami, którzy w dodatku zostają napiętnowani w charakterystycznej dla czasów PRL gazetce ściennej (s. 24-26), a także zwalczanie przesądów - postać chłopa-złomiarza, który skarży się na trafienia pioruna, próbując je odgonić przy pomocy „okadzania i obrazów w oknach” (s. 34-35). Wzorowi harcerze podejmują także prace społeczne, pomagając w ramach akcji Niewidzialnej Ręki (s. 40) i wprowadzają usprawnienie racjonalizatorskie w postaci kurtki z prądem, znane już widzom filmów Polskiej Kroniki Filmowej z lat $60 .^{15}$

Księga III (1968) przynosi pewną zmianę stylu oraz rzeczywistości przedstawionej: chłopcy podróżują w kosmosie, zaś wstęp do tej części przygód jest wyraźnie stylizowany na narrację naukową (s. 1). W całym tomiku nie brakuje fantastycznych zjawisk i stworzeń (lunaszek, kosmoczki, karbulot itd.), które są opisywane $\mathrm{z}$ iście encyklopedyczną precyzją i przedstawiane w postaci tablic naukowych przypominających wyposażenie szkolnych pracowni. Interesująco pod względem konceptualnym propaguje Chmielewski zrzeszanie się w organizacjach harcerskich (s. 43-53), proponując młodym czytelnikom wizję planety z ,rozległą nudosferą", na której chłopcy zakładają zastęp harcerski, angażując do niego miejscowych mieszkańców. Nieodłącznym elementem scenariusza jest „stworek-oporek”, indywidualista kontestujący otwarcie ideę zrzeszania się w zgranym, harcerskim kolektywie; w końcu jednak, ulegając presji większości, składa samokrytykę i wstępuje do miejscowego zastępu ZHP.

Księga IV (1969) stanowi niemal jawną propagandę Ludowego Wojska Polskiego. Być może nie jest sprawą przypadku, że tę księgę wydano rok po tragicznych marcowych wydarzeniach 1968 roku oraz inwazji na Czechosłowację - dokładnie bowiem odpowiadałaby ona na niewyrażone wprost potrzeby propagowania pozytywnego wizerunku LWP. Po infantylnej zabawie w wojnę chłopcy postanawiają uczestniczyć w prawdziwym przysposobieniu wojskowym, by

\footnotetext{
${ }^{15}$ Por. materiał Kurtka z pradem.
} 
zdobyć Młodzieżowe Odznaki Sprawności Bojowej (s. 21). Narrację uzupełniają wpisane w komiks tablice edukacyjne prezentujące sprzęt wojskowy. Obok zabawnych elementów przekazu (długowłosy zwykle Romek zostaje ostrzyżony „na jeża”) pojawiają się także i takie, które mają charakter kłamliwej wręcz propagandy historycznej, zgodnej z wytycznymi tamtego czasu: na s. 28 czytelnik znajduje planszę przedstawiającą zdobycie Warszawy. Na planszy nie ma wojsk Armii Czerwonej, które w istocie w styczniu 1945 roku wkroczyły do stolicy. W rzeczywistości o „wyzwoleniu” nie było mowy (a już na pewno nie wyłącznie przez Polaków), ponieważ decyzją Stalina wojska te wjechały do miasta już zrujnowanego i wykrwawionego w wyniku spacyfikowania Powstania Warszawskiego $^{16}$. Obrazek ten, zajmujący jedną zaledwie stronę, wpisuje się w kłamliwą narrację historyczną PRL o rzekomym wyzwoleniu Warszawy.

Wizerunki żołnierzy, jak i cały obraz LWP, zostały na kartach tej księgi zaprezentowane pozytywnie, bez wyjątków, skaz, słabych punktów. Na s. 41 czytelnik zastaje wojskowych pracujących w czynie społecznym, tj. koszących zboże na zaniedbanym polu ${ }^{17}$, a całości obrazu dopełnia wypowiedź A’Tomka z ostatniej stronicy: „Dziękujemy za zaproszenie i miły pobyt. Niech żyje Ludowe Wojsko Polskie!" (s. 54).

Ksiegga V (1970), opisująca podróż chłopców „do ćwierć koła świata”, jest jak dotąd najbardziej nasycona treściami politycznymi. Podróże po krajach Europy Zachodniej autor wykorzystał, by w zabawnym entourage'u zaprezentować charakterystyczne atrakcje turystyczne i cechy tych krajów, ale także stereotypy (w Londynie mgła i picie herbaty o godz. 17, w Paryżu obecność kloszarda). Wyraźne nasilenie treści propagandowych czytelnik obserwuje, gdy bohaterowie lądują w Nowym Jorku. Poznają tam współczesne społeczeństwo kapitalistyczne i konsumpcjonizm posunięty do granic absurdu (inwazyjną i zakłamaną reklamę, napady gangsterów na bank), wreszcie obserwują zachowania rasistowskie (s. 31-38). Wszystkie te negatywne cechy amerykańskiej rzeczywistości są natychmiast skontrastowane $\mathrm{z}$,tygodniowym pobytem u kubańskich przyjaciół” (s. 42) i osobistym spotkaniem z Fidelem Castro.

Wątek amerykański pojawia się ponownie, gdy chłopcy trafiają na Saharę i tam - wyczerpani z pragnienia - znajdują studnię. Okazuje się jednak, że dostępu do niej strzeże amerykański automat, zaś kubek wody kosztuje 10 centów.

A'Tomek: Czy dlatego, że nie mamy centa przy duszy, mamy umierać z pragnienia!? Tytus (rozbija automat): Życie ludzkie jest ważniejsze, niż czyjeś małe interesy.

(Księga V, s. 49)

${ }^{16}$ Zob. P. Wieczorkiewicz, Agonia niepodległości, [w:] tenże, Historia polityczna Polski 1935-1945, Zysk i S-ka, Poznań 2014, s. 525-612.

${ }^{17}$ Przypomina to ośmieszane przez satyryka Jacka Fedorowicza Wojskowe Gospodarstwa Rolne w latach 80 . 
Wizja Ameryki jako siedliska bezdusznego, odhumanizowanego kapitalizmu pojawiała się w licznych przekazach propagandowych, także w produkcjach Polskiej Kroniki Filmowej - eksploatowano tam wątki militarne, szpiegowskie, pokazywano także „zwyrodniałą” amerykańską kulturę i sztukę ${ }^{18}$. Autor komiksu ograniczył się do pokazania „odhumanizowanych” stosunków społecznych w USA, robiąc to jednak w sposób naprawdę sugestywny. Obrazu dopełnia międzynarodowy socjalistyczny obóz pionierów; na ostatnich stronach księgi można nawet zauważyć (po raz pierwszy i bodaj ostatni w serii) flagi radzieckiej.

Księga VI (1971) - jakkolwiek nie zawiera wyraźnych treści o charakterze propagandowym - zdaje się zapowiadać zmianę scenariusza totalitarnego, tym razem realizowanego przez ekipę Edwarda Gierka. Kluczowym pojęciem dla pierwszej połowy dekady lat 70 . jest bez wątpienia ,propaganda sukcesu” oraz hasło: „aby Polska rosła w siłę, a życie jej obywateli było bardziej dostatnie”. Poprawa stopy życiowej wielu obywateli PRL, otwarcie się na Zachód oraz jego dobra konsumpcyjne, a także zachodnie kredyty - wszystko to składało się na widoczny rozwój gospodarczy, będący pozytywną odmianą w porównaniu do biednych, oszczędnych lat rządów „ponurego, ascetycznego” Gomułki. Jak zauważa Świda-Ziemba, starsi już wówczas przedstawiciele pokolenia „małej reformy i wielkiego buntu" koncentrowali się przede wszystkim na poprawie sytuacji materialnej oraz zapewnieniu swoim dzieciom lepszych niż sami mieli warunków kształcenia i startu w dorosłe życie: „Ci, których było na to stać, obdarowywali dzieci prezentami (ubrania, pieniądze, urządzenia elektroniczne), oczekiwali od nich sukcesów $\mathrm{w}$ nauce, a w małym stopniu zdawali sobie sprawę z ich psychiczno-emocjonalnych potrzeb"19. Autorka odnotowuje również, że w owym czasie zmieniła się szkoła; sama, pracując wówczas jako nauczyciel akademicki, obserwowała proces odchodzenia nauczycieli starszego pokolenia „z wyraźnym etosem zawodowym” oraz charakterystyczną w tym zawodzie „selekcję negatywną” - zawód nauczyciela wybierano tylko z konieczności, jako nisko płatny i mało prestiżowy ${ }^{20}$ - co musiało w sposób widoczny wpływać negatywnie na jakość kształcenia, autorytet nauczyciela, a w rezultacie - na stosunek do obowiązku szkolnego. Przemiany polityczno-społeczne i realizowanie scenariusza ekipy Gierka zaowocowało pojawieniem się pokolenia scharakteryzowanego przez Świdę-Ziembę jako „pokolenie podmiotowości i więzi wspólnotowej”. Szkoła ze swoją fasadowością i gigantomanią uroczystości ku czci socjalizmu nie miała młodzieży nic do zaoferowania, rodzice zaś, zaabsorbowani bogaceniem się, często rezygnowali z jakiejkolwiek więzi emocjonalnej ze swoimi dziećmi. Pojawia się więc pokolenie, w którym najbardziej liczą się wartości indywidualne, koncentracja na sobie, swojej osobowości

\footnotetext{
${ }^{18}$ Por. produkcje PKF z lat 50. Oto Ameryka i Go home.

${ }^{19}$ H. Świda-Ziemba, dz. cyt., s. 487.

${ }^{20}$ Tamże, s. 488.
} 
i nastrojach, z drugiej zaś strony - potrzeba emocjonalnej więzi z drugim człowiekiem bądź grupą ludzi.

$\mathrm{Na}$ tym tle powstają kolejne zeszyty serii, w których bohaterowie nabierają pewnych cech indywidualnych, zaś ich język - wyrazistości. Rzecz ciekawa, że Księga VI po raz pierwszy nie zawiera jednoznacznie pozytywnego zakończenia. Przygotowania Tytusa do olimpiady w duchu szlachetnej rywalizacji sportowej i kultu zdrowego ciała okazują się zupełnie niepotrzebne: A’Tomek pomylił olimpiadę sportową z olimpiadą szachową.

Ksiege VII (Tytus poprawia dwójkę z geografii Polski, 1972) można traktować jako alegoryczny obraz pierwszej połowy dekady Gierka i jego propagandy sukcesu. Przede wszystkim rzuca się w oczy jej polonocentryzm; o ile akcja innych tomików rozgrywa się w różnych, często wymyślonych częściach świata bądź w kosmosie, tym razem zostaje osadzona w polskich realiach, od czasów prehistorycznych po socjalistyczną współczesność. Stąd promowanie polskiego przemysłu:

A'Tomek: Bardzo ważna dziedzina jest górnictwo i hutnictwo. [...] Niech poprawkowicz przyjrzy się, właśnie odbywa się wylew surówki.

Tytus: Nie lubię surówek, ale subtropikalne goraco huty bardzo mi odpowiada.

(Księga VII, s. 13)

Propagandowe uwagi A’Tomka są w ciekawy sposób kontrowane przez humorystyczne, niekiedy absurdalne docinki Tytusa. Nie zmienia to faktu, że ,poprawkowicz" musi zwiedzić i rozpoznać inne zakłady przemysłowe: Kombinat Siarkowy w Tarnobrzegu, Zakłady „Azoty” w Puławach czy bliżej niezidentyfikowaną cukrownię.

Podobnie jak w tomikach poprzednich przesądy są traktowane z politowaniem bądź szyderstwem:

Tytus (widząc głaz): Skąd się wziąt? Zapewne najlepiej będzie wiedziała gospodyni pola.

Gospodyni: Lepiej nie pytaj, synku. Kiedy budowano tu klasztor, nie podobało się to Lucyferowi i rzucit na budowe głaz, ale nie trafit. Głaz upadt na takę.

Romek: ,, Gtaz upadt na takę... .'. A'Tom, przez cate wakacje niczego go nie nauczymy. A'Tomek: Nie tacy wychodzili na ludzi.

(Księga VII, s. 15)

Interesujące jest, że w takim właśnie kontekście po raz pierwszy pojawia się jakakolwiek wzmianka o klasztorze i Lucyferze, a więc atrybutach katolickości. Wcześniej bowiem autor starannie unikał jakichkolwiek słów mogących kojarzyć się z religią. 
Na s. 22 czytelnik pozna kolejny pomysł racjonalizatorski:

Spoza ramki: Co to za pudto?

Romek: Pralnia. Nie zdejmując odzieży wchodzi do środka brudas i dzięki bombardowaniu suchymi detergentami po paru minutach wychodzi czysty i pachnacy.

Jak widać i w tej księdze nie brakuje wynalazków, które są coraz bardziej nowoczesne. Na s. 46 prezentowany jest nawet Instytut Genetyki i Hodowli Zwierząt PAN, choć pokazany w trochę groteskowym stylu (dziwne krzyżówki genetyczne zwierząt), ma być zapewne świadectwem dynamicznego rozwoju kraju i dalszego jego unowocześniania.

Mimo obecności treści identyfikowanych jako propagandowe, zakończenie znowu sugeruje, że poprawka Tytusa nie jest traktowana serio. Zdaje ją tylko dzięki znalezionemu w zamku malborskim eliksirowi Mondralicum alergicum. Samo zaliczenie odbywa się na plaży, gdzie pod koniec wakacji wypoczywa nauczyciel. Tytus egzamin zdaje, ale potem, gdy eliksir przestaje działać, pyta: „Panowie, ten Bałtyk to właściwie jezioro czy ocean?”. Wyczuwa się w tym zachowaniu reakcję na fasadowość systemu szkolnictwa oraz jego bylejakość. Sztuczna, naznaczona rytuałami rzeczywistość szkolna nie tylko nie była atrakcyjna, ale też nie dawała się w żadnej mierze potraktować poważnie. Mogli ją tak traktować zindoktrynowani harcerze pokroju Romka i (zwłaszcza!) A’Tomka, ale z pewnością nie przeciętna młodzież, szukająca wśród rówieśników wspólnoty poglądów, śmiechu, ale także melancholii (a nawet nastrojów depresyjno-filozoficznych). I z pewnością nie mógł jej poważnie traktować spryciarz Tytus, skory do draki i zabawy. Notabene tomik zaczyna się od okładek książek, którymi szympans chwali się kolegom - a są to książki z kręgu rozrywkowej literatury amerykańskiej.

W serii trafiały się również księgi okolicznościowe, jak np. Księga VIII, wydana w 1973 roku z okazji Roku Kopernikańskiego ogłoszonego przez ekipę Gierka. W ramach jego obchodów podjęto liczne inicjatywy odbudowy i rozbudowy miejsc oraz zabytków związanych z Mikołajem Kopernikiem. Warto dodać, że w tej dekadzie (podobnie jak w latach 60.) szczególnie głośno celebrowano rocznice związane z Polską i jej historycznymi postaciami czy wydarzeniami, o ile nie kolidowały one w wyraźny sposób z totalitarną historiografią. Rocznicę Bitwy Warszawskiej 1920, powstania AK czy urodzin Józefa Piłsudskiego oczywiście trudno byłoby sobie wyobrazić, niemniej rocznica urodzin Kopernika okazała się przydatna w propagandzie sukcesu i starannym zacieraniu obrazu rzeczywistości PRL jako marionetkowego kraju w obozie komunistycznym, zdominowanego przez ZSRR. Podejmowano inicjatywy mające Polaków przekonać, że Polska Ludowa jest mimo wszystko Polską - wolną, suwerenną, w której można i należy troskliwie zabiegać o zabytki, dbać o dobra narodowe oraz celebrować urodziny wybitnego polskiego astronoma. 
Takie właśnie zadania stają przed zastępem harcerskim z udziałem bohaterów komiksu. Z ciekawszych pomysłów odnotowujemy aparacik do przenoszenia w czasie i przestrzeni oraz (po raz pierwszy na łamach) postać prof. T. Alenta. Pozostałe elementy - podróże w czasie, obserwowanie co ciekawszych wydarzeń i zabawne pokazanie realiów historycznych - służą dydaktyce przez rozrywkę. Zasada „uczyć bawiąc” nadal obowiązywała, choć podróże chłopców są już naznaczone przypadkiem oraz niedoskonałością przegrzewającego się aparaciku.

Księga IX (Tytus na Dzikim Zachodzie, 1974) jest znakiem popularności westernów nadawanych w telewizji PRL w latach 70., będących niewątpliwie częścią kultury amerykańskiej - nie daje się jednak zauważyć w komiksie wyraźnego przekazu propagandowego. Trudno tu także znaleźć wyraźne treści dydaktyczne i wychowawcze. Wracają one w Księdze X (Ochrona przyrody, 1975), w której Tytus i chłopcy przeżywają na dzikiej, dziewiczej wyspie „rozwój cywilizacji” w skrócie: od epoki kamienia łupanego do epoki żelaza i współczesnego przemysłu. Pojawia się znów (choć już nie tak nachalna) promocja wartości harcerskich. Na s. 11 A’Tomek zwraca się do hipopotama z przerośniętymi zębami: „Biedny. Masz szczęście, że trafiłeś na harcerzy. Harcerz miłuje przyrodę, pomożemy ci... Przyniesiemy pilnik z mielolotu [kolejnego baśniowego pojazdu pomysłu J. Chmielewskiego - przyp. KG] i spiłujemy ci zęby".

Tomik zawiera ciekawe pod względem stylistyczno-językowym dialogi, które świadczą o zmianie strategii autora:

Romek: Ciekawe, co wytupat Tytus?

Tytus: Wytupałem telewizor „Granit” 23 cale. Następnie wylupię samochód, samolot, $i \ldots$

A’Tomek: A jak wyłupiesz prąd i benzynę, zgłoś się do poradni zdrowia psychicznego. (Księga X, s. 15)

Taka złośliwość wydaje się niegodna harcerza według wzoru ZMP-owskiego, jakim dotąd był A’Tomek. Poza tym w tomiku ujawnia się jego władcza postawa, zarozumialstwo, zapędy przywódcze i... uchylanie się od wszelkiej pożytecznej pracy. Te cechy będą się nasilać w kolejnych księgach - a są dowodem na to, że bohaterowie Chmielewskiego nabierają wyrazistości i charakteru. Świadczą o tym także tchórzostwo i złośliwość (niekiedy wyraźna agresja werbalna i fizyczna) Romka, a także coraz bardziej odważny i zadziorny charakter Tytusa. Te zmiany wpływają na wymowę komiksu - traci on swój propagandowo-dydaktyczny charakter, a staje się ciekawie pomyślaną rozrywką.

Interesujące jest jednak to, co dzieje się na stronach 49-53, a więc w zakończeniu komiksu. Chłopcy odkrywają źródło ropy naftowej i zabierają się do jej przetwórstwa, by zyskać paliwo do unieruchomionego fantastycznego pojazdu, tzw. mielolotu. Tymczasem Tytus orientuje się, że efekty tego przetwórstwa spowodo- 
wały katastrofę ekologiczną: wyspa umiera, drzewa usychają, ptaki i zwierzęta uciekają bądź zdychają, wody powierzchniowe zamieniają się w ścieki. Chłopcy uruchamiają mielolot i uciekają. Sytuację ratuje Papcio Chmiel (w swoich licznych wtrętach autotelicznych staje się bowiem niekiedy bohaterem swoich komiksów). Rysuje filtry oraz oczyszczalnię ścieków i zapowiada odrodzenie się przyrody.

Oto po raz pierwszy na łamach komiksu pojawia się sytuacja, w której działania głównych bohaterów są przyczyną katastrofy i zniszczeń. Z drugiej strony jednak pojawia się „magiczna ręka” autora, podejmująca działania naprawcze, ekologiczne. Cały komiks miał być poświęcony ochronie przyrody, a w rzeczywistości jest odniesieniem do realiów związanych z uprzemysłowieniem kraju w latach 70. Gigantyczna Huta Katowice i wielkie zakłady przemysłowe rozbudowywane były bez żadnego rozsądku i stosownych zabezpieczeń ekologicznych, co powodowało liczne zanieczyszczenia środowiska tak często podnoszone przez różnych dziennikarzy w czasach $\mathrm{PRL}^{21}$. W istocie więc dbałość o ekologię i o środowisko naturalne w PRL była fikcją. W tej sytuacji Księgę X można traktować jako próbę usprawiedliwienia PRL-owskiego przemysłu, zwłaszcza w ostatniej scenie. O tym jednak, że jest to nieprawda, świadczy sytuacja ekologiczna wielu obszarów PRL do 1989 roku, a także problemy obecne ${ }^{22}$.

Księga XI (Ochrona zabytków, 1977), podobnie jak księga kopernikańska, również ma charakter polonocentryczny i - zgodnie z ówczesną polityką władz PRL - propaguje troskę o „,dobra narodowe”. Harcerze podróżują po Polsce fantastycznym pojazdem latającym, tzw. prasolotem, i restaurują zabytki, starając się jednocześnie wykorzystać je turystycznie i zorganizować w nich jakieś placówki: głównie harcówki bądź muzea. Po raz pierwszy pojawia się bohater epizodyczny o charakterze irracjonalnym: duszek. Tytus i Romek okazują mu sympatię; ten pierwszy wyraźnie widzi w nim partnera do zabawy. A'Tomek zaś, jako wzorowy post-ZMP-owiec, traktuje go wyraźnie instrumentalnie:

A’Tomek: Żaden dowcip nie zastuguje na wyróżnienie.

Romek: A'Tom, skąd się tu wziateś?

A'Tomek: Aby mieć pieczę nad zastępem, uwierzyłem na chwilę w duchy i przerzucilo mnie za wami.

(Księga XI, s. 12)

O przedmiotowym traktowaniu komiksowego duszka świadczy także wkręcanie wentyla dla łatwiejszego nadmuchiwania, wykorzystywanie go do wyciągania

\footnotetext{
${ }^{21}$ Por. publikację pamiętnikarską Stefana Maciejewskiego oraz jego teksty dziennikarskie traktujące o ekologii na terenie Krakowa i okolic (S. Maciejewski, Wojna polsko-polska. Dziennik 1980-83, Wydawnictwo Księgarnia Akademicka, Warszawa 2007).

22 Por. przekazy telewizji informacyjnych w Polsce (w tym telewizji TVN24) na temat zagrożenia smogowego w dniach 3-10 stycznia 2017 roku.
} 
pojazdu z bagna itd. Można te sceny interpretować jako daleką alegorię instrumentalnego podejścia do pewnych wartości pozasystemowych (np. duchowych) przez komunistów do osiągania własnych celów, z wyraźnym zastrzeżeniem, że takie myślenie i działanie nie jest już powszechne, a charakterystyczne jedynie dla zindoktrynowanych działaczy.

Narracja jest uzupełniona zabawnymi scenami fikcyjnymi, które oddają koloryt epoki (tyrania otyłego króla Jedzosława czy rycerskie przygody w średniowieczu), ale nie mają wyraźnego charakteru dydaktycznego. Nie znaczy to jednak, że zeszyt ten jest całkowicie pozbawiony treści dydaktyczno-wychowawczych; oto na s. 29-31 bohaterowie trafiają w starej olejarni na chuliganów (oczywiście pijących niedozwolony alkohol), przedstawionych jako idioci. Chłopcy wraz z duchem postanawiają ich uspołecznić oraz dokształcić (przez symboliczne wlanie oleju do głowy). Warto zaznaczyć, że Chmielewski dorysował chuliganom długie włosy, co może sugerować przynależność do subkultury hippisów. Podobnie wychowawczy charakter mają sceny na s. $56-57$, tj. walka z plagą komarów przy pomocy naprędce skręcanych cygar, w których działanie tytoniu zaprezentowane jest w groteskowy sposób - chłopcy po zapaleniu cygar mdleją i doznają halucynacji.

Interesujący jest fakt, że tomik ma zakończenie pozytywne: Tytus otrzymuje złotą odznakę Zasłużonego Opiekuna Zabytków za odrestaurowanie ziemianki i przerobienie jej na atrakcję turystyczną o charakterze historycznym - skansen wojskowy. Propagowanie wzoru idealnej młodzieży zatem powraca.

Księga XII (Operacja Bieszczady, 1977) wydaje się banalna, przypomina bardziej „eksplorację” tytułowego terenu czy jego cywilizowanie i wpisuje się w strategię „dbania o dobra narodowe”. Na początku autor w zabawny sposób ustosunkowuje się do bajki opowiadanej dzieciom, że to bociany przynoszą rodzicom niemowlęta. Wyczerpany bocian prosi Tytusa o dostarczenie dzieci i wręcza mu kartkę z adresem:

Karta dostawcza nr 235

Artykuł: dziecko

Rodzaj: męski

Gatunek: Słowiański

Liczba: 2 sztuki

Odbiorca: Słodkowscy, Adamowo.

(Księga XII, s. 4)

Zamiast obserwowanej do tej pory negatywnej, szyderczej postawy wobec przesądów i lokalnych wierzeń, Chmielewski postanowił posłużyć się stylizacją na język stosowany w branży handlu detalicznego.

Chłopcy jako wzorowi harcerze mają wykonać w Bieszczadach szereg zadań, m.in. zbudować stanicę harcerską oraz sprawić, by teren stał się ekologiczną 
enklawą zwierząt. Podejmują się ponownie różnych racjonalizatorskich operacji, nie zawsze kończących się dobrym efektem, ale zawsze zabawnych. Pomylenie źródeł pesy- i optycoli da się na szczęście naprawić przez mądrego zastępowego A’Tomka.

Dialogi są cięte, dowcipne i ciekawe. Na s. 23 pojawiają się sceny świadczące o dalszej ewolucji charakterów głównych bohaterów. Gdy Tytus zostaje porwany i wykorzystany przez miejscowych kłusowników do produkcji zarobkowych zdjęć, chłopcy, aby go wybawić z opresji, zaczynają powoli używać „niedozwolonych" metod: wprowadzać w błąd, niekiedy kłamać (np. dla zmylenia drogi), uciekać harcerzowi, który zatrzymał ich za brak karty rowerowej... Są sprytni, ale przy tym niepokorni. Nie ma w nich widocznej w pierwszych zeszytach infantylnej grzeczności.

W Księdze XIII (Wyprawa na wyspy nonsensu, 1979) autor korzysta z okazji, by zaprezentować czytelnikowi kilka obserwacji socjologicznych. Księga została opublikowana w roku 1979, u schyłku dekady Gierka. W kraju narastał potężny kryzys gospodarczy, zadłużenie było bardzo wysokie, na rynku brakowało wielu towarów niezbędnych do egzystencji. Istniała już i rozwijała się opozycja polityczna. W komiksie nie ma oczywiście śladu tych realiów, niemniej w ich kontekście wizja niektórych wysp nonsensu wydaje się dość odważna. Pierwsza odwiedzona przez chłopców wyspa (s. 9-14) stanowi obraz wypaczonej, rozdętej do absurdalnych granic biurokracji (taczki pełne kwitów, mieszkańcy wyspy o głowach w kształcie pieczątki itd.) i niewątpliwie jest ironicznym odniesieniem do zbiurokratyzowanej rzeczywistości PRL. Pozostałe wyspy - robotów, sportowców oraz głupich dowcipów - nie zawierają treści o charakterze propagandowym, ale podczas ich zwiedzania można obserwować wyraziste, niekiedy negatywne zachowania i przejawy charakterów głównych bohaterów. Na s. 23 czytelnik staje się świadkiem bójki między Romkiem a Tytusem, którzy coraz częściej obrzucają się także wymyślnymi inwektywami.

Zdecydowanie ciekawsza jest zaprezentowana na s. 45-54 wyspa palaczy. Jest ona $\mathrm{w}$ istocie szyderczą alegorią obsesyjnej propagandy antynikotynowej w PRL. Mieszkańcy wyspy są zaczadzeni nie tylko dymem, lecz także natarczywą propagandą pronikotynową. Cały system szkolnictwa, relacji społecznych i osobistych oparty jest na tytoniu i paleniu. Tytus trafia do rezerwatu, gdzie doprowadza do rewolucyjnego przewrotu pod kryptonimem „Oxygenium”. A i tak zostaje skrytykowany przez A’Tomka:

Tytus: Dziękuję, jesteście harcerzami, a nie stanęliście po stronie niepalacych. A'Tomek: Mamy tylko badać wyspy nonsensu i relacjonować profesorowi. A ty przez bunt $w$ rezerwacie naruszyteś stan faktyczny.

(Księga XIII, s. 54) 
Powyższy cytat jest sygnałem pewnego przewartościowania - odstępstwa od charakterystycznej dla wczesnych okresów rozwoju totalitaryzmów zasady poprawiania rzeczywistości (w tym natury) za wszelką cenę. Kolejne drobne zmiany tego typu dostrzega się w Księdze XIV (Nowe metody nauczania, 1980); mimo braku wyraźnych treści propagandowych, przynosi ona drobne zmiany w stroju bohaterów (znikają mundurki harcerskie) oraz swobodne podejście do obowiązku szkolnego (elektroniczne metody nauczania, w wyniku których Tytus w parę minut zdobywa wykształcenie doktorskie).

Księga $\boldsymbol{X V}$ (Tytus geologiem, 1982) ma charakter wyraźnie przełomowy. $\mathrm{O}$ ile w poprzedzających ją tomach dało się obserwować malejące natężenie treści propagandowych i krystalizowanie się charakterów głównych postaci, o tyle w księdze „geologicznej” autor niemal całkowicie zmienia strategię: postanawia sięgnąc po język ezopowy i aluzję polityczną. W drugiej połowie komiksu bowiem tworzy czytelną analogię państwa totalitarnego. Na s. 33 chłopcy podczas swojej podziemnej podróży wkrętaczem trafiają na uprzemysłowioną przestrzeń, która pierwotnie wydaje im się podziemną fabryką. Rychło się przekonują, że „fabryka” jest w istocie podziemnym państwem krasnali. Charakterystyczne jest to, że przed oblicze Najniższego zostają doprowadzeni siłą i pod bronią, a następnie wbrew swojej woli zmniejszeni do rozmiaru krasnoludów. Same krasnale okazują się zmilitaryzowane: posiadają rozbudowany arsenał rakietowy (służący nie tylko do zmniejszania i zwiększania ludzi i zwierząt), a nawet pistolety laserowe $^{23}$. Podczas wspólnego obiadu Najniższy wyjaśnia:

Cha, cha, nie znacie naszego poglądu na świat. Krasnoludkoizm głosi, że jedynie przez miniaturyzację człowieka będzie można wyżywić ludzkość. Po wyprodukowaniu 2 miliardów rakiet „LILI-PUT” wyjdziemy na powierzchnię i zaczniemy zmniejszać ludzi. W drugiej fazie zmniejszymy zwierzęta niepożyteczne.

(Księga XV, s. 41)

Poza ekspansywnym poglądem na świat, czytelnicy poznają inne elementy państwa totalitarnego: prezentację pomników związanych z systemem i ideologią (przedstawionych jako kult postaci z bajek braci Grimm; s. 42), fasadowość charakterystyczną dla komunizmu (na s. 45 Najniższy zdejmuje „służbową” brodę i czapkę krasnala), wyraźne zapędy militarne (uwaga ze s. 50 o niszczeniu „niepożytecznych" dla krasnali zwierząt). Uwaga Tytusa może przywodzić na myśl wszystkie obawy związane z wyścigiem zbrojeń oraz napięć między Wschodem i Zachodem: „Niszcząc «niepożyteczne» zwierzęta, zachwiejecie równowagą naturalną i doprowadzicie do końca świata" (s. 50). W końcowych scenach okazuje się, że chłopcy zostali uwięzieni, są inwigilowani, a ich podziemny pojazd zniszczono.

${ }^{23}$ Por. s. 43 - fikcyjna „kawiarnia” strzeżona przez uzbrojonego krasnala-strażnika. 
Tę alegorię systemu totalitarnego - przemyconą pod postacią zmyślnej opowieści o uzbrojonych po zęby krasnalach - można ocenić jako wyjątkowo odważną. Nie ma wprawdzie żadnej paraleli między bajkową rzeczywistością a realiami ustrojowymi PRL, niemniej autor zaczyna młodym czytelnikom sugerować, jak wygląda totalitarna rzeczywistość. Trudno ocenić, na ile wizja była czytelna dla ówczesnych nastolatków, ale w owym czasie po komiksy Chmielewskiego sięgali także przywiązani do serii starsi czytelnicy.

Ksiega XVI (Tytus dziennikarzem, 1981) przedstawia przygodę Tytusa w redakcji tygodnika „Trele-Morele” i sama w sobie nie zawiera istotnych z punktu widzenia ideologii PRL treści. Dydaktyzm jest realizowany przez przekazywanie wiedzy o ówczesnej polskiej prasie i metodach jej druku - oznacza jedynie tyle, że Chmielewski niekiedy wracał do funkcji edukacyjnej, choć na skalę znacznie mniejszą niż wcześniej.

Ksiega XVII (Uczłowieczenie Tytusa przez umuzykalnienie, 1985) - podobnie jak następująca po niej Księga XVIII z 1987 roku - jest dowodem zasadniczego zwrotu $\mathrm{w}$ strategii perswazyjnej autora. Nie tylko nie zawiera ona jakichkolwiek treści propagandowych związanych z PRL, ale stanowi zdecydowaną krytykę ustroju totalitarnego opartego na wzorze sowieckim. Współczesny czytelnik może dostrzec w niej to, co Świda-Ziemba nazywa ,agonią systemu”24. Charakter dydaktyczny czy oświatowy mogą mieć jeszcze wtręty o badaniu Tytusa przez laryngologa, w których pada kilka łacińskich określeń oraz pojawiają się objaśnienia, na czym polega badanie słuchu i czym zajmuje się laryngologia. Na tym jednak autor poprzestaje.

Zmiana strategii jest sygnalizowana od pierwszej strony poprzez język. Pojawia się cytat bełkotliwej nowomowy telewizyjnej: ,[...] stabilność nowych bodźców ekonomicznych efektywnie stymuluje [...]" (s. 1), który znakomicie oddaje nudę ówczesnej telewizyjnej propagandy, zwłaszcza dotyczącej gospodarki. Sami bohaterowie są już bardzo wyraziście sportretowani. Tytus generalnie od początku był zadziorny i dość samodzielny emocjonalnie, niemniej cechy tej postaci i jej ekscentryczność są już pokazane wręcz hiperbolicznie. Szympans wpada bez wyraźnego powodu w szał, realizuje różne zwariowane pomysły, podejmuje wiele samodzielnych inicjatyw. Posługuje się językiem tyleż oryginalnym, co złośliwym i nawet agresywnym, o czym świadczą cytaty: „Ta klasyczna nuda dobra dla wąskonosych emerytów doprowadza mnie do szału!” (s. 15), „Miaucz! Poświęć się dla nauki i sztuki, nędzna kreaturo śmietnikowa!” (do schwytanego kota; s. 24). W całym zeszycie obserwuje się ciekawe, niezwykle kreatywne zabiegi językowe, ciekawe wykorzystanie istniejących nazw zespołów muzycznych: Flegma II, Prosektorium, Kasa Chorych, czy dowcipna wymiana zdań osób tańczących w dyskotece.

\footnotetext{
${ }^{24}$ H. Świda-Ziemba, dz. cyt., s. 568.
} 
Dopełnieniem indywidualizacji postaci Tytusa jest jego kariera jako twórcy współczesnej muzyki elektronicznej i industrialnej o charakterze wyraźnie postmodernistycznym. Cały tomik jest zresztą nasycony technologią związaną z zapisem dźwięku, współczesnym intrumentarium, komputerami, wyrafinowaną elektroniką; naznaczony nowoczesnym, zachodnim podejściem do muzyki. Nie znaczy to, że muzyki elektronowej lub konkretnej dotąd w Polsce nie znano ${ }^{25}$, niemniej położenie akcentu na eksperyment w sztuce wydaje się znaczące.

Z punktu widzenia prowadzonej analizy najciekawsze i najważniejsze treści pojawiają się od s. 38, gdy Tytus spotyka przybyszów z planety Neuma i zostaje przez nich porwany. Muzyczna rewolucja, jaką Tytus przeprowadza na Neumie (planecie dźwięków) jest oczywiście zabawna, ale nosi cechy ustrojowe państwa totalitarnego według wzorów sowieckich. Świadczą o tym następujące wydarzenia:

- Tytus zostaje predyskozydentem;

- planeta dzieli się na dwa obozy: decybelan i cichoszan (co przypomina wyraźnie podział świata podczas zimnej wojny: obóz socjalistyczny i zachodni);

- szybko konstytuuje się opozycja polityczna pod nazwą Bojowa Organizacja Antyhałasowa i pod przewodnictwem dra Otitisa (który wprost mówi o „obaleniu przybłędy z Ziemi”);

- pojawiają się liczne pomniki na cześć Tytusa i inne oznaki kultu wodza w Redyskopublice.

Widać również charakterystyczną dla totalitaryzmu gigantomanię, przedstawioną pod postacią olbrzymich mikrofonów, kolumn głośnikowych i wszystkich atrybutów kojarzonych z muzyką. Godło (mikrofon na tle kasety magnetofonowej) oraz wszelkie inne pomysły są również wprowadzane bądź akceptowane jednoosobowo. Być może nie ma większego znaczenia, że mikrofon ma kolor sierpa (stalowy), zaś kaseta jest czerwona.

Niezwykle wyrazistym odniesieniem do sowietyzmu jest oświadczenie Tytusa:

Tytus: Oto moje pierwsze dekrety:

1. Kto nie tańczy, ten nie je.

2. Wszyscy tańczący są sobie równi.

3. Znosi się ciszę nocną.

4. Wejście na dyskoteki dla młodych małżeństw bezpłatne.

(Księga XVII, s. 44)

${ }^{25}$ Por. audycję Józefa Patkowskiego Radio: problemy z 1961 roku, w której autor charakteryzuje ówczesne elektroniczne metody zapisu i przetwarzania dźwięku oraz opisuje działalność Studia Eksperymentalnego Polskiego Radia i prezentuje muzykę elektronową. 
O ile w punkcie 3. dostrzega się wyraźną kpinę, tak punkt 4. jest już czytelnym ironicznym odniesieniem do lat 80 . i tzw. kredytów dla młodych małżeństw, podobnie jak punkt 2. jest postulatem równości głoszonym oficjalnie w doktrynie komunistycznej. Na sowiecki charakter ustroju wskazuje jednak dekret pierwszy: jest on parafrazą okrutnej zasady stosowanej w sowieckich obozach pracy: „kto nie pracuje, ten nie je"26.

System Tytusa ma oczywiście swój aparat opresji: na s. 49 przywódca opozycji Otitis zostaje aresztowany i wtrącony do ,przyzwyczajalni akustycznej”, gdzie prezentuje się głośną muzykę (poza więzieniem są i elementy tortur). Pojawiają się wrogie rządowi demonstracje i napisy na murach. Obrazu „muzycznej rewolucji” na Neumie dopełnia metaforyka wojenna i komiczna broń (miny i bariery dźwiękowe, pojazdy bojowe dźwiękoszczelne itd.). Ostatecznie, co znamienne, państwo totalitarne zostaje obalone, zaś Tytus - sprowadzony na Ziemię.

Księga XVIII (Tytus plastykiem, 1987) zwiastuje koniec socjalizmu. Dydaktyzm jest ograniczony do wiedzy o różnych nurtach w malarstwie, ale są to głównie nurty modne na Zachodzie w XX wieku, takie jak abstrakcjonizm czy kubizm (jak wiadomo, taką sztukę w propagandzie lat 50. PRL traktowano jako zwyrodniałą). Sami bohaterowie nie mają już w sobie nic z pokornych uczniów i wzorowych harcerzy, są dojrzewającymi młodzieńcami, pełnymi emocji i popędów odpowiednich dla tego wieku (Tytus nawet zakochuje się w kubistycznej bohaterce jednego z obrazów). Najlepszym dowodem na zerwanie z propagandą PRL jest jednak wymiana zdań ze s. 25:

Egipcjanin: Pierwszy raz ciebie widzę. Ską jesteś?

Tytus: $Z$ Polski.

Egipcjanin: Czy tam jest ustrój niewolniczy?

Tytus: $O$, przeszliśmy już feudalizm, socjalizm, a teraz mamy kapitalizm $i$ w soboty nie pracujemy.

W wypowiedzi zawierającej nutę wyraźnie satyryczną pojawia się jeden z postulatów sierpniowych „Solidarności” (wówczas nielegalnej), a słowo „socjalizm” pojawia się po to, by zasygnalizować koniec tego ustroju. Wprawdzie w czasie wydania tomiku hasła „głasnost” i ,pierestrojka” już funkcjonowały ${ }^{27}$, kraje bloku socjalistycznego stopniowo reformowały swoje gospodarki, otwierając się na ekonomię kapitalistyczną (prawdziwą reformę w Polsce rozpoczął dopiero Leszek Balcerowicz po przemianach Okrągłego Stołu w 1989 roku), niemniej niezwykle daleko było jeszcze do jakiegokolwiek ,kapitalizmu”, który wieszczył Tytus.

${ }^{26}$ Zasada wielokrotnie przywoływana w publikacji Aleksandra Sołżenicyna. Por. tenże, Archipelag Gułag, tłum. J.M. Pomianowski, Dom Wydawniczy Rebis, Poznań 2008.

${ }^{27}$ M. Gorbaczow, Przebudowa i nowe myślenie dla naszego kraju i całego świata, przeł. A. Kurkus, J. Malczyk, Warszawa 1988. 
Podsumowując - bohaterowie kierowani ludzkimi emocjami, promowanie trendów sztuki modnych na Zachodzie i w USA (kubizm, abstrakcjonizm, ogólnie wolność w sztuce) oraz niezwykle odważne, nawet jak na późny PRL, dialogi - świadczą wyraźnie o agonii systemu i niemal całkowitym jego zdezawuowaniu, a także o odrzuceniu jego propagandy przez Chmielewskiego.

\section{Wnioski}

1) Analiza tomików o Tytusie, Romku i A'Tomku wydawanych w okresie PRL dowodzi ewolucji obrazu propagowanych wartości. Autor rozpoczął od wręcz nachalnej propagandy adresowanej do starszych dzieci i młodzieży w latach 60 ., zgodnej ze scenariuszem totalitarnym wprowadzonym przez ekipę Gomułki. W pierwszych zeszytach znajdziemy więc apoteozę wszystkich wartości wzorowego harcerza i młodego obywatela PRL, który poprawia i naprawia rzeczywistość, propaguje dobre wzorce, walczy z przesądami, dobrze się uczy w szkole, pracuje społecznie. Są elementy ewidentnej krytyki czy potępienia amerykańskiego kapitalizmu, z drugiej strony zaś pochwalny, wręcz entuzjastyczny obraz Ludowego Wojska Polskiego. Te treści bez wątpliwości można nazwać propagandowymi. W dekadzie Gierka pojawiają się elementy - choć już nie tak natrętne - propagandy sukcesu: głównie podróże po uprzemysłowionych rejonach kraju i pokazywanie fabryk budowanych oraz propagandowo prezentowanych w tym czasie choćby w Polskich Kronikach Filmowych.

Dopiero na przełomie lat 70. i 80. następuje przełom w przekazie perswazyjnym komiksu. Natężenie treści propagandowych maleje niemal do zera, autor zaczyna również rezygnować z dydaktyczno-wychowawczej funkcji przekazu (choć odbywa się to stopniowo i z różną wyrazistością). W ostatnich księgach następuje wręcz odrzucenie podstawowych założeń ustrojowych PRL jako państwa totalitarnego. Nie można było tego wyrazić wprost, więc pokazano podziemne państwo zmilitaryzowanych krasnali oraz próby stworzenia przez Tytusa dyktatury na Neumie, opartej na wzorze sowieckim (autor nie stronił już od aluzji w pełni zrozumiałych). Młodzi czytelnicy mogli nie dopatrzeć się znaczenia tych aluzji, ale starsi, kupujący komiks z sentymentu bądź przyzwyczajenia, mieli już szansę je rozszyfrować. W latach 70. zaczęto sprowadzać i czytać nielegalną literaturę (książki Aleksandra Sołżenicyna, Czesława Miłosza i innych), natomiast dekadę później pojawił się nielegalny obieg publicystyczny i literacki. Dla czytelników nieco bardziej zorientowanych w realiach politycznej rzeczywistości taki przekaz mógł być już całkowicie czytelny. Ostatnim elementem upadku systemu sygnalizowanym w komiksie była promocja popularnych na Zachodzie nurtów plastycznych i muzycznych 
oraz kilka charakterystycznych cytatów, które wskazywały na jednoznaczne odrzucenie socjalistycznych „wartości”. W tym celu warto było posłużyć się nawet nazwami ustrojów politycznych i społecznych, które do tej pory w księgach w ogóle się nie pojawiały.

2) Portrety psychologiczne bohaterów podlegają ewolucji: wraz z kolejnymi tomikami rosną, dorośleją. Wizualnie się nie zmieniają (mowa o rysach twarzy czy figurach), ale wyraźnie zmienia się ich charakter. Ich język początkowo jest dziecinny (piosenki i rymowanki), zachowania ugrzecznione. W połowie lat 70. pojawiają się ciekawsze, cięte dialogi, autor operuje lepszym retorycznie dowcipem językowym, głębszą myślą. Charaktery się krystalizują, pojawiają się elementy tyleż negatywne, co niezbędne i zwyczajne prawdziwe: lenistwo i przywódcze zapędy A’Tomka, tchórzostwo, konfliktowość i złośliwość Romka, a także cwaniactwo, spryt i nieokiełznany charakter Tytusa, u którego z czasem pojawia się coraz więcej młodzieńczych popędów i emocji. Są elementy agresji, zarówno fizycznej, jak i językowej. Na oczach czytelnika chłopcy stają się inteligentnymi młodzieńcami, mającymi swoje indywidualne cechy charakteru, niepozbawionymi również wad. W swoich zachowaniach, także językowych, oddalają się od wzorca idealnej młodzieży PRL. Już w latach 70. ich harcerskie role przestają być wyraziste, ostatecznie Chmielewski z nich rezygnuje.

3) Język i retoryka - infantylne, propagandowe, wręcz męczące stają się stopniowo coraz bardziej dojrzałe, ciekawsze. Stopniowo - od mniej więcej 6-7 zeszytu Chmielewski rozwija humor językowy, nie stroniąc nie tylko od dowcipu, ale także ironii, sarkazmu, szyderstwa. Pojawiają się określenia agresywne (choć jeszcze nie wulgarne) wyrażenia, określenia i zwroty: „Tempo, tępolu, tempo!” czy „nędzna kreaturo śmietnikowa” i „ten przybłęda z Ziemi”. Kontekst tych wyrażeń na ogół jest komiczny, ale bywa również znaczący.

Nie można dziś jednoznacznie twierdzić, że przynajmniej część czytelników czytała komiks przez pryzmat rzeczywistości PRL, identyfikując $\mathrm{w}$ jego pierwszych numerach treści propagandowe lub wychwytując w ostatnich numerach aluzje krytyczne wobec systemu komunistycznego. Stwierdzenia takie wymagałyby przeprowadzenia stosownych badań. Jedno jest pewne - ten komiks w bardzo ciekawy sposób, jak w soczewce, pokazuje propagandę „wartości PRL” i ewolucję tej propagandy aż do ostatnich lat, słusznie określanych przez Świdę-Ziembę jako „agonia systemu”. 


\section{Bibliografia}

Bralczyk J., O języku propagandy i polityki, Wydawnictwo Trio, Warszawa 2007.

Chmielewski H.J., Tytus zlustrowany. Autobiografia na tle historii komiksu pt. „Tytus, Romek i A'Tomek", Młodzieżowy Dom Kultury w Opolu, Opole 2006.

Czelakowska A., Kilka uwag o aktach językowego znieważania, „Język Polski” 2006, nr 1, s. 20-26.

Dobek-Ostrowska B., Fras J., Ociepka B., Teoria i praktyka propagandy, Wydawnictwo Uniwersytetu Wrocławskiego, Wrocław 1997.

Dobrzyńska Teresa, Mówiąc przenośnie... Studia o metaforze, Instytut Badań Literackich PAN, Warszawa 1994.

Garczyński S., Anatomia komizmu, Krajowa Agencja Wydawnicza, Warszawa 1986.

Gorbaczow M., Przebudowa i nowe myślenie dla naszego kraju i całego świata, przeł. A. Kurkus, J. Malczyk, Państwowy Instytut Wydawniczy, Warszawa 1989.

Habrajska G., Nakłanianie, perswazja, manipulacja językowa, „Acta Universitatis Lodziensis. Folia Litteraria Polonica" 2005, t. 7, cz. 2, s. 91-125.

Historia polityczna świata XX wieku. 1945-2000, red. M. Bankowicz, Wydawnictwo Uniwersytetu Jagiellońskiego, Kraków 2004.

Mazur M., Propagandowy obraz świata. Polityczne kampanie prasowe w PRL 1956-1980. Model analityczno-koncepcyjny, Wydawnictwo Trio, Warszawa 2003.

Ożóg K., Język w stużbie polityki, Wydawnictwo Uniwersytetu Rzeszowskiego, Rzeszów 2004.

Sołżenicyn A., Archipelag Gułag, przeł. J.M. Pomianowski, Dom Wydawniczy Rebis, Poznań 2008.

Sowa A.L., Historia polityczna Polski 1944-1991, Wydawnictwo Literackie, Kraków 2011.

Świda-Ziemba H., Młodzież PRL. Portrety pokoleń w kontekście historii, Wydawnictwo Literackie, Kraków 2010.

Krzysztof Grzegorzewski

Picture of Polish People's Republic in Henryk Jerzy Chmielewski’s

comic book series "Tytus, Romek and A'Tomek"

(analysis of books from period 1966-1987)

(Summary)

Author analyses a popular comic book series by H.J. Chmielewski, Tytus, Romek \& A'Tomek (book from 1966-1987) and tries to reconstruct a propagandist vision of the Polish Peoples Republic's reality. The main research tool is a content analysis of book, using knowledge of the political history of Poland and the world (1945-1989), social and mass communication context, history of media in Poland and rhetorics. Author describes the results, in relation to book by sociologist, Hanna Świda-Ziemba: The youth of Polish People's Republic.

Keywords: Polish People's Republic, political history, history of media, propaganda, comic book, rhetoric. 